\title{
Dry matter production and nitrogen utilization in cropping systems with grass, lucerne and maize. 1. Comparison of crop characteristics, growth and production
}

\author{
L. Sibma and J. H. J. Spiertz \\ Centre of Agrobiological Research (CABO), P.O. Box 14, 6700 AA Wageningen, \\ Netherlands
}

Received 11 April 1985; accepted 5 June 1985

Key words: forage production, grass, lucerne, maize, dry matter, nitrogen, specific leaf area, light interception, root/shoot ratio

\begin{abstract}
Dry matter production and crop characteristics of lucerne were studied in comparison with grass and maize under temperate conditions. Annual dry matter yields of lucerne ranged from 13.4 to 18.1 tonnes $\mathrm{ha}^{-1}$ and were comparable to those of grass and maize. However, the digestibility of lucerne was lower than that of grass cut for silage and that of maize; so, the yield of digestible organic matter hardly could compete with that of grass and of maize.

Crop characteristics determining growth rate and duration were studied. Despite significant differences in leaf/stem ratio, specific leaf area and leaf area index, full light interception was achieved with the same amount of dry matter for grass and lucerne. After defoliation by cutting, the duration to a closed crop canopy did not differ.

The decline in plant density of lucerne during successive growing seasons was studied; the decline in tap root number was compensated by the number of shoots per tap root. Dry matter losses of lucerne by root and shoot senescence were measured.

It was concluded that the yield potential of lucerne could be improved by breeding for earlier varieties with a good persistence of roots and shoots.
\end{abstract}

\section{Introduction}

Fossil energy use in agriculture has risen considerably during the past few decades because of its relatively low prices compared with the cost of land and labour. In the Netherlands energy costs for forage production are mainly determined by the amount of fertilizer nitrogen used on permanent grassland. With the rise of energy prices and, as a consequence, higher prices of nitrogen fertilizer there is increasing 
interest in the use of perennial forage legumes as inexpensive nitrogen sources in crop production (Heichel et al., 1981).

Although high-nitrogen dressings on grassland enhance the herbage yield, concurrently the energy output:input ratio is lowered and the risks of water and soil pollution are increased. From this point of view restricted nitrogen fertilizer inputs are a necessity for energy saving and for protecting the environment from nitrate leaching.

These developments and constraints in forage production raised the need for more information on cropping systems with forage legumes. In 1979 a three-year experiment was started to study growth, yield and crop characteristics of grass, lucerne and maize. This paper deals with growth, forage yield and quality, distribution of dry matter, root/shoot-ratio, leaf characteristics and light interception. The data on nitrogen yield and nitrogen fixation will be presented and discussed in a second paper (Sibma \& Spiertz, 1986); that paper also includes the residual effects of the various cropping systems on the dry matter and nitrogen yield of the following crop maize.

\section{Material and methods}

Nine cropping systems with grass, lucerne and maize were studied during three consecutive years. The sequence and duration of the crops are presented in Table 1. The experiment started in August 1979, by sowing grass and lucerne at a seed rate of 25 and $30 \mathrm{~kg} \mathrm{ha}^{-1}$, respectively. The seed rate for maize in the spring of 1980 was $30 \mathrm{~kg} \mathrm{ha}^{-1}$. In the following years the same seed rates were applied. The cropping systems consist of:

- G1, G2 and G3 for the cultivation of perennial ryegrass during one, two and three years, respectively

- L1, L2 and L3 for the cultivation of lucerne in the same way

- M1, M2 and M3 for the cultivation of maize with arable crops and a mixture of grass and lucerne.

The 9 cropping systems with 4 replicates resulted in 36 sub-blocks. Each sub-

Table 1. Sequences of the cropping systems with the three main crops (italicized) grass, lucerne and maize in the years $1980-1983$. In 1983 the test crop was maize.

\begin{tabular}{llll} 
& 1980 & 1981 & 1982 \\
G3 & Grass & Grass & Grass \\
G2 & Winter wheat & Grass & Grass \\
G1 & Maize & Spring wheat & Grass \\
L3 & Lucerne & Lucerne & Lucerne \\
L2 & Winter wheat & Lucerne & Lucerne \\
L1 & Maize & Spring wheat & Lucerne \\
M3 & Lucerne/grass & Maize & Maize \\
M2 & Winter wheat & Lucerne/grass & Maize \\
M1 & Maize & Spring wheat & Maize \\
\hline
\end{tabular}


Table 2. Crops, varieties, sowing dates and $\mathrm{N}$ dressings of the cropping systems.

\begin{tabular}{|c|c|c|c|c|}
\hline $\begin{array}{l}\text { Cropping } \\
\text { system }\end{array}$ & Crop & Variety & $\begin{array}{l}\text { Sowing } \\
\text { dates }\end{array}$ & $\begin{array}{l}\text { N supply kg } \\
\text { ha }^{-1} \text { year }^{-1}\end{array}$ \\
\hline \multicolumn{5}{|l|}{1980} \\
\hline G3 & Perennial ryegrass & (B.G-3) & $1979-08-20$ & 440 \\
\hline L3 & Lucerne & Europe & $1979-08-20$ & - \\
\hline M1 & Maize & Fronica & $1980-05-02$ & $0-40-80-160$ \\
\hline \multicolumn{5}{|l|}{1981} \\
\hline G3 & Perennial ryegrass & (B.G-3) & & $0-142-285-437$ \\
\hline $\mathrm{G} 2$ & Perennial ryegrass & (B.G-3) & $1980-08-15$ & $0-142-285-437$ \\
\hline L3 & Lucerne & Europe & & $0-150-300-450$ \\
\hline L2 & Lucerne & Europe & $1980-08-15$ & $0-150-300-450$ \\
\hline M3 & Maize & Irla & 1981-04-28 & $0-75-150-225$ \\
\hline \multicolumn{5}{|l|}{1982} \\
\hline G3 & Perennial ryegrass & (B.G-3) & & $0-150-300-450$ \\
\hline $\mathrm{G} 2$ & Perennial ryegrass & (B.G-3) & & $0-150-300-450$ \\
\hline $\mathrm{G} 1$ & Perennial ryegrass & (B.G-3) & 1981-07-31 & $0-150-300-450$ \\
\hline L3 & Lucerne & Europe & & $0-150-300-450$ \\
\hline $\mathrm{L} 2$ & Lucerne & Europe & & $0-150-300-450$ \\
\hline L1 & Lucerne & Europe & 1981-07-31 & $0-150-300-450$ \\
\hline M3 & Maize & LG 11 & $1982-04-28$ & $0-75-150-225$ \\
\hline $\mathrm{M} 2$ & Maize & LG 11 & $1982-04-28$ & $0-75-150-225$ \\
\hline M1 & Maize & LG 11 & $1982-04-28$ & $0-75-150-225$ \\
\hline \multirow[t]{2}{*}{1983} & $\begin{array}{l}\text { (Test crop maize on } \\
\text { all plots) }\end{array}$ & & & \\
\hline & Maize & Irla & 1983-06-06 & $\begin{array}{l}\text { No } \mathrm{N} \text { fertilizer ex- } \\
\text { cept } \mathrm{M} 1 \\
0-75-150-225\end{array}$ \\
\hline
\end{tabular}

block was divided into 4 plots with different nitrogen dressings. Information on crops, regarding choice of varieties, sowing dates and level of nitrogen dressings, is presented in Table 2. During the first full growing season in 1980 the nitrogen dressing for all grass plots amounted to $440 \mathrm{~kg} \mathrm{ha}^{-1} \mathrm{year}^{-1}$. During that year lucerne did not receive any nitrogen fertilizer. Maize received nitrogen fertilizer at four different levels.

A wide range of fertilizer nitrogen dressings equal to those on grass were applied to lucerne since 1981. The difference in nitrogen yield between a legume and a nonfixing crop was used as an estimate of the nitrogen fixation. Nitrogen dressings to lucerne were applied to show how fixation is excluded by the amount of nitrogen available in the soil. The hypothesis that higher dry matter yields of lucerne may be expected when more mineral nitrogen is available and fixation is excluded could be tested with a range of nitrogen dressings.

After an early harvested winter wheat crop a new series of the three crops was started in August 1980 and 1981. As a consequence of this experimental setup the best opportunity for comparing the various forage crops was in the growing season 
of 1982 (see Table 1).

In 1980 every fortnight the following measurements were carried out in the G3, L3 and M3 plots: fresh and dry weights of leaves and stems, leaf area, light interception and nitrogen content of the crops.

In 1981 and 1982 intermediate sampling was more restricted; however in 1982, besides the aboveground growth analysis of lucerne, the amount of roots was determined in 4 replicates of $0.25 \mathrm{~m}^{2}$. The roots were dug out to $50-60 \mathrm{~cm}$ depth and the number of crowns and sprouts was counted. Root mass in the deeper layers turned out to be very low; therefore root sampling was restricted to a depth of $60 \mathrm{~cm}$.

Digestibility 'in vitro' was determined according to the generally accepted method described by Tilley \& Terry (1963) with some modifications. Together with each set of samples a number of standard samples with known organic matter digestibility coefficient in vivo $\left(\mathrm{D}_{\mathrm{om}}\right.$ in $\mathrm{g} \mathrm{g}^{-1}$ ) were analysed. From the results of these standard samples a regression formula was calculated which is used to predict $D_{o m}$ in vivo for the unknown samples.

The experiment was carried out at the experimental farm of the Agricultural University at Flevoland on soil with a clay fraction of $39 \%, \mathrm{pH}-\mathrm{KCl} 7.3$, organic matter content $4.8 \%$, P-total (expressed as $\mathrm{P}_{2} \mathrm{O}_{5}$ ) $1.5 \%$, a soil nitrogen content of $0.13 \%$. This soil contains a large content of potassium $(220 \mathrm{mg} / \mathrm{kg})$ and magnesium $(155 \mathrm{mg} / \mathrm{kg}$ ). During the growing period the water-table is around $1.80 \mathrm{~m}$. These characteristics are favourable for arable crops and lucerne. Shallow-rooting grass may suffer from water shortage during drought spells; with maize early growth is delayed, because of low soil temperatures.

For yield assessments strips of $10 \mathrm{~m} \times 1.5 \mathrm{~m}$ were harvested from the plots with a total size of $13 \mathrm{~m} \times 9 \mathrm{~m}$. In between samples of $0.25 \mathrm{~m}^{2}$ were taken out of the border strips for growth analyses of shoots and roots.

\section{Results}

\section{Growth patterns of grass and lucerne}

Fig. 1. shows the pattern of growth and number of cuts during the growing season. In early spring the growth of lucerne was first slower than the growth of grass. The first-year lucerne crop showed a delayed growth pattern compared with grass in 1980 and 1981 (see Fig. 1). This delay may be caused by the relatively late sowing date in the preceding year (see Table 2). The reversed pattern in 1982 may be explained by the delay in grass growth caused by winter damage in the second- and third-year grass. Apparently the first-year grass crop (G1) suffered less from the winter conditions, which resulted in more growth during spring. The winter damage can be demonstrated by the dry matter yields in May of grass in 1980, 1981 and 1982; on 20 May these yields were 7, 6 and 3 tonnes ha ${ }^{-1}$, respectively.

The importance of early growth in May for the total yield of lucerne is demonstrated by the growth curves for the first- and second-year crop in 1981. An advantage in yield early in the season is maintained until the end of the season (Fig. 1). It is a common feature of grass and lucerne that growth rates during spring are higher than in late summer. 

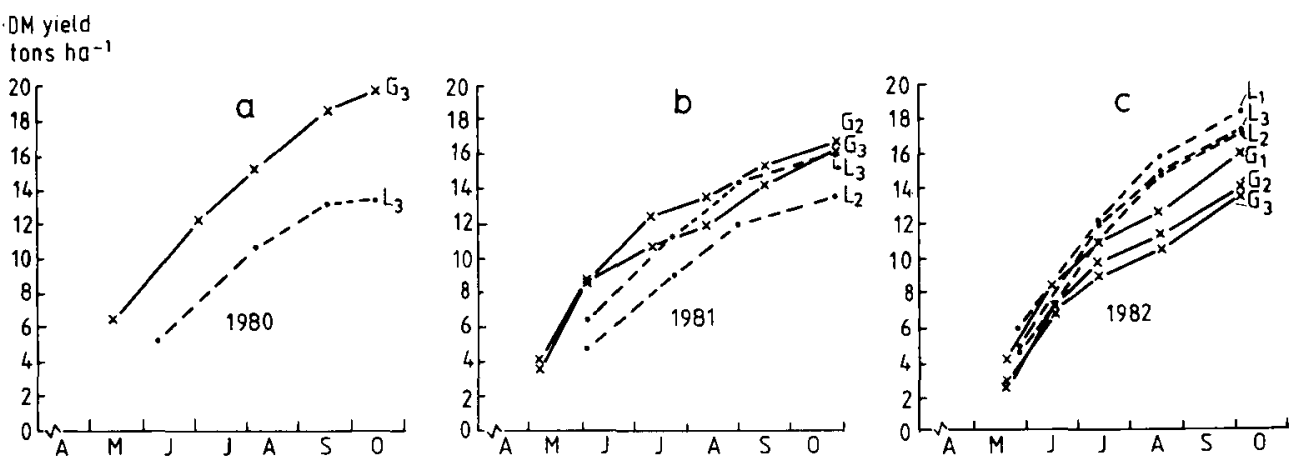

Fig. 1a. Increase and total of dry matter yields of 1st-years grass (G3) with 5 cuts and of 1st-year lucerne (L3) with 4 cuts in 1980.

Fig. 1b. Increase and total of dry matter yields of 2nd- and 1st-year grass (G3 and G2) and of 2nd and 1st year lucerne (L3 and L2) in 1981.

Fig. 1c. Increase and total of dry matter yields of 3rd-, 2nd- and 1st-year grass $(\mathrm{G} 3,2,1)$ and lucerne (L3, $2,1)$ in 1982.

Dry matter yields and digestibility of grass, lucerne and maize

Dry matter yields (DM), and digestible organic matter yields (DOM) are presented in Table 3. The presentation of the data is restricted to grass and maize with the highest nitrogen dressings and lucerne without nitrogen dressing. More data on the yield response to nitrogen are presented elsewhere (Spiertz \& Sibma, 1986).

Table 3. Dry matter yields (DM) in tonnes $\mathrm{ha}^{-1} \mathrm{year}^{-1}$ and digestible organic matter (DOM) in tonnes ha $^{-1}$ year $^{-1}$.

\begin{tabular}{|c|c|c|c|c|c|c|}
\hline \multirow[b]{3}{*}{ Grass } & \multicolumn{2}{|l|}{1980} & \multicolumn{2}{|l|}{1981} & \multicolumn{2}{|l|}{1982} \\
\hline & $\overline{\mathrm{DM}}$ & $\mathrm{DOM}^{*}$ & $\overline{\mathrm{DM}}$ & $\mathrm{DOM}^{*}$ & $\mathrm{DM}$ & $\mathrm{DOM}^{*}$ \\
\hline & & & & & & \\
\hline G3 & 19.8 & 12.9 & 16.2 & 11.4 & 13.4 & 9.1 \\
\hline G2 & - & - & 16.7 & - & 13.9 & 9.5 \\
\hline G1 & - & - & - & - & 15.8 & 10.7 \\
\hline \multicolumn{7}{|c|}{ Lucerne } \\
\hline L3 & 13.4 & 7.2 & 16.0 & 9.8 & 17.2 & 9.8 \\
\hline L2 & - & - & 13.6 & 8.4 & 17.1 & 9.8 \\
\hline L1 & - & - & - & - & 18.1 & 9.9 \\
\hline Maize & 13.7 & 9.5 & 16.1 & 11.2 & 17.1 & 11.8 \\
\hline
\end{tabular}

* $\mathrm{DOM}=\mathrm{DM}(1$-fraction ash $) \times \mathrm{D}_{\mathrm{om}}$.

Significances for total DM ha ${ }^{-1}$ year $^{-1}$ :

1980: $\mathrm{L} 3<\mathrm{G} 3$

1981: $\mathrm{L} 2<(\mathrm{G} 2+\mathrm{G} 3) / 2 ; \mathrm{L} 3 \approx(\mathrm{G} 2+\mathrm{G} 3) / 2 ; \mathrm{L} 3 \approx \mathrm{L} 2 ; \mathrm{L} 3 \approx \mathrm{G} 3$

1982: $\mathrm{L} 1 \approx \mathrm{L} 2 \approx \mathrm{L} 3>\mathrm{G} 1>\mathrm{G} 2 \approx \mathrm{G} 3$

$>$ or $<=$ significant at $95 \%$ level $; \approx=$ not significant at $95 \%$ level. 
Dry matter yields were relatively high in the three experimental years. However, clear differences were found between and within seasons. The first-year grass crop yielded 19.8, 16.7 and 15.8 tonnes $\mathrm{ha}^{-1}$ in 1980,1981 and 1982 , respectively. In this experiment a first-year grass crop attained a higher yield level, than a second- and third-year crop.

The dry matter yields of the first-year lucerne crop were $13.4,13.6$ and 18.1 tonnes $\mathrm{ha}^{-1}$ in 1980,1981 and 1982, respectively. In 1981 a second-year crop yielded 2.4 tonnes ha ${ }^{-1}$ more than a first-year crop, but in 1982 there were hardly any differences. It may be concluded that with good crop management the yield potential of lucerne is maintained during three consecutive years.

Despite the higher dry matter yields of lucerne compared with grass in 1982, the yield of digestible organic matter only slightly differed between grass and lucerne. This was caused by the much lower digestibility coefficient $\left(\mathrm{D}_{\mathrm{om}}\right)$ of lucerne (ranging from 0.627 to 0.725 ) compared to that of rye-grass (ranging from 0.723 to 0.844 ). For both crops the yields of DOM were around 10 tonnes ha $^{-1}$ (Table 3 ).

For maize a digestibility coefficient of 0.730 was assumed (Struik, 1982). The low ash content and the high digestibility of maize result in a relatively high yield of digestible organic matter. Under the climatic conditions of the Netherlands the digestible organic matter yields (DOM) of maize outyielded that of lucerne. The DOM yields were $9.5,11.2$ and 11.8 tonnes $\mathrm{ha}^{-1}$ in 1980,1981 and 1982 , respectively.

\section{Specific leaf area, leaf/stem ratio and light interception}

For analysing growth limitations of grass and lucerne the leaf/stem dry weight ratio, light interception and specific leaf area (SLA) were measured. At different growth stages the leaf/stem ratio was higher with grass than with lucerne (Fig. $2 \mathrm{a}$ ). If the specific leaf area of lucerne and grass were the same lucerne would need a higher dry matter production to attain an equal leaf area index.

In 1980 SLA values were measured for grass and lucerne. Comparison of the SLA on the same dates show that the SLA values of lucerne were higher than those of grass (Fig. 2b). Thus lucerne is able to reach full light interception with less investment of dry matter in leaves than grass. So, despite the unfavourable leaf/stem ratio, full light interception was reached with the same amount of dry matter. Taking total dry matter production into account, 90 to $100 \%$ of full light interception was achieved with about 2 tonnes of dry matter per ha for lucerne as well as for grass (Fig. 2c). Besides differences in SLA and leaf angle, leaf distribution within the canopy was more favourable for lucerne than for grass (Woodward \& Sheehy, 1979).

The seasonal pattern of light interception of grass and lucerne is illustrated in Fig. 3 , based on data of a second-year crop in 1981. With lucerne light interception is less than with grass at the beginning of growth in spring and after each cut. The recovery of full light interception for grass and lucerne takes about 20-25 days (see Fig. 3). The accumulation of incomplete light interception as fractions of the days resulted in 1980 and 1981, in a loss of 39 and 40 growing days for grass and of 52 and 34 growing days for lucerne, respectively. So it may be concluded that the fractional loss of light interception in lucerne was not considerably higher than in grass. An advantage of lucerne is the longer duration of an undisturbed closed crop canopy 


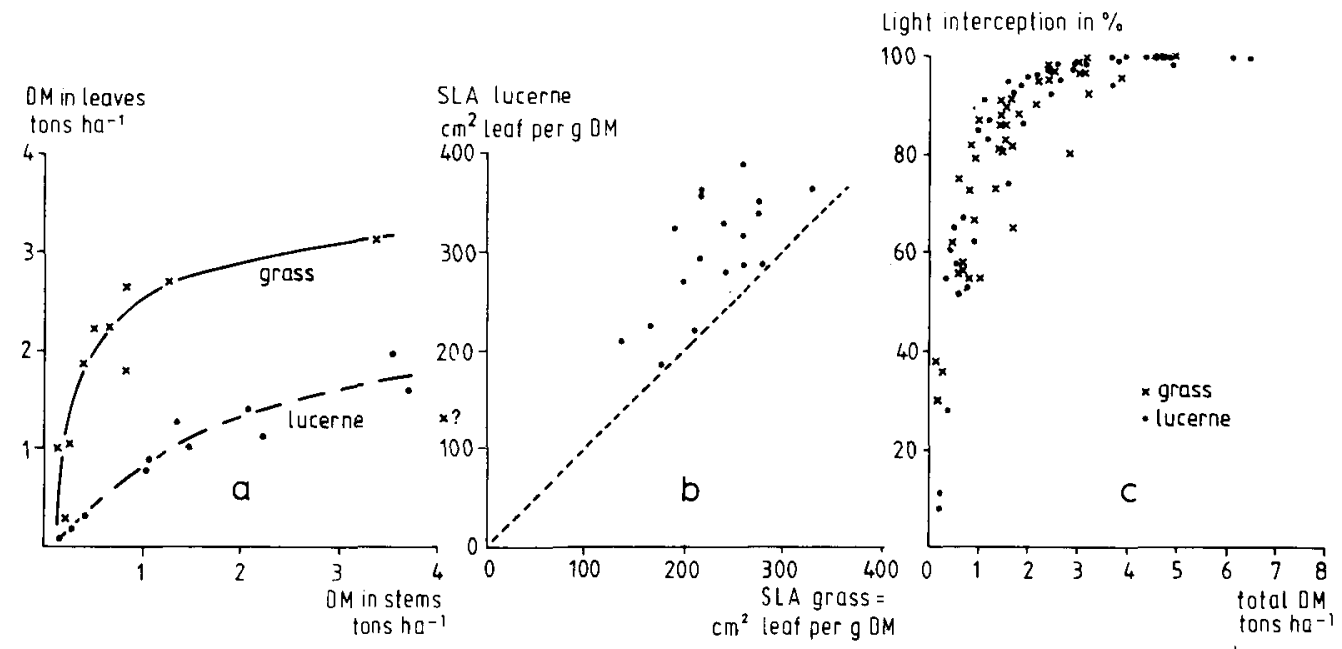

Fig. 2a. The difference in dry weights of leaves and stems between grass (G3) and lucerne (L3) in 1981. Fig. 2b. The relation between specific leaf area (SLA) of grass (G3) and of lucerne (L3) harvested on the same dates in 1980.

Fig. 2c. The relation between total dry matter yield and light interception in 1981 in grass (G3) and lucerne (L3).

between two cuts; a disadvantage to the yield potential is the relatively slow leaf growth and development in spring.

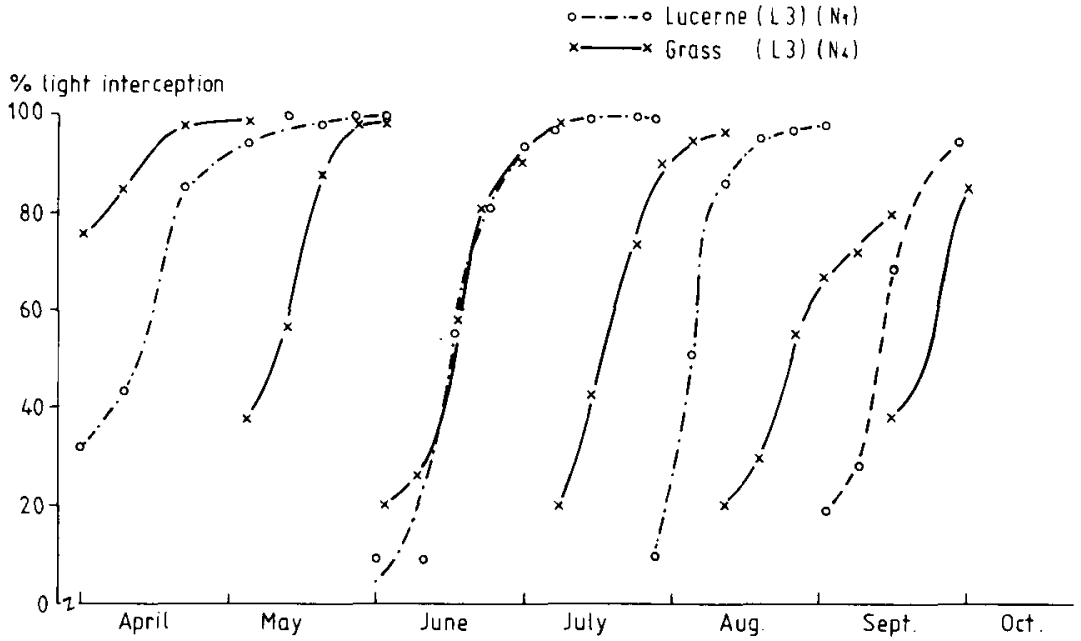

Fig. 3. The pattern of light interception in a second-year grass crop and a second-year lucerne crop in 1981. 
Changes in weight and number of roots and shoots of lucerne

To study the effect of ageing on shoot and root density of lucerne measurements were carried out in the plots without nitrogen dressing and with $450 \mathrm{~kg} \mathrm{ha}^{-1} \mathrm{year}^{-1}$ in 1982. Nitrogen dressing hardly showed any effect, therefore in Fig. 4 the data are presented as an average of the nitrogen dressings. The decrease in number of tap roots is sharp in the first-year crop: from about 400 roots $\mathrm{m}^{-2}$ in spring to about 225 roots $\mathrm{m}^{-2}$ in autumn. In the second-year crop there was a smaller loss of roots and plant density, and decrease was lowest in the third-year crop (about 60 roots $\mathrm{m}^{-2}$ ). Decrease in tap root number mainly took place during the period from April to July. This pattern may be associated with the greater biomass production during the first and second cut and as a consequence a stronger light competition.

The root mass of the three lucerne crops in spring and autumn is presented in Table 4. Root mass in a first-year crop in April was $146 \mathrm{~g} \mathrm{~m}^{-2}$ and in a three-year crop in october $618 \mathrm{~g} \mathrm{~m}^{-2}$. With only 123 roots $\mathrm{m}^{-2}$ a three-year crop invested more dry matter in the tap roots including the crown. The dry weight of the individual roots evidently increased even more: from $0.4 \mathrm{~g}$ to $5.0 \mathrm{~g}$ per root.

There was some experimental evidence that the weight of the roots slightly increased during the period from late October until mid-April (Table 4). No samples were taken during this period; so that pattern of dry weight gain or loss could not be followed during the period of 'dormancy'.

A decrease in the number of tap roots was associated with an increase in the number of shoots per tap root (Table 4). The number of shoots per root in the spring of 1982 was 2.5 in a first-year crop and 6.4 in a third-year crop. This compensation in shoot number offsets the decline in number of roots during successive growing seasons (Fig. 4).

Within a season the number of shoots decreased during each growth cycle. At the
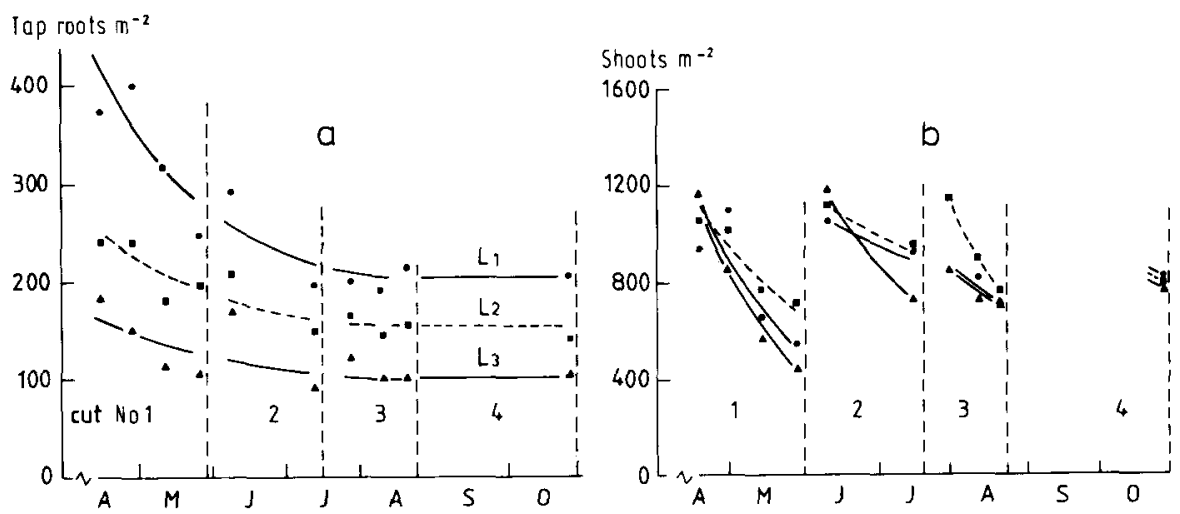

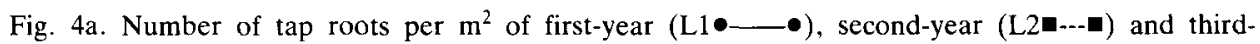
year (L3 $\mathbf{A}-\mathbf{A}$ ) lucerne in 1982.

Fig. 4b. Number of shoots per $\mathrm{m}^{2}$ of first-, second- and third-year lucerne in 1982. For legend see Fig. 4a. 
Table 4. Dry matter weights and number of roots and shoots of a first-, second- and third-year crop of lucerne in 1982.

\begin{tabular}{|c|c|c|c|c|c|c|}
\hline & \multicolumn{3}{|c|}{ Dry matter in roots + crowns } & \multirow[b]{2}{*}{$\begin{array}{l}\text { Tap roots } \\
\mathrm{m}^{-2}\end{array}$} & \multirow[b]{2}{*}{$\begin{array}{l}\text { Shoots } \\
\mathrm{m}^{-2}\end{array}$} & \multirow[b]{2}{*}{$\begin{array}{l}\text { Shoots per } \\
\text { crown }\end{array}$} \\
\hline & & $\mathrm{g} \mathrm{m}^{-2}$ & $\mathrm{~g}$ root $^{-1}$ & & & \\
\hline \multirow[t]{2}{*}{ L1 } & April & 146 & 0.4 & 369 & 928 & 2.5 \\
\hline & October & 385 & 1.5 & 254 & 821 & 3.2 \\
\hline \multirow[t]{2}{*}{ L2 } & April & 397 & 1.6 & 241 & 1052 & 4.4 \\
\hline & October & 505 & 3.2 & 157 & 802 & 5.1 \\
\hline \multirow[t]{2}{*}{ L3 } & April & 621 & 3.5 & 180 & 1147 & 6.4 \\
\hline & October & 618 & 5.0 & 123 & 788 & 6.4 \\
\hline
\end{tabular}

beginning of the growing season and after each cut new shoots were formed; however, this increase was offset by the senescence of shoots in a dense stand.

\section{Discussion}

A limiting factor for the dry matter yield of lucerne is the slow development of a canopy during early spring and as a consequence less growth compared with a grass crop. From observations of lucerne grown under controlled conditions at different root temperatures it is concluded that soil temperatures in spring are too low for rapid growth. The response of lucerne to root temperatures of a nutrient solution ranging from $10,15,20$ to $25^{\circ} \mathrm{C}$ and a constant air temperature of about $17^{\circ} \mathrm{C}$ was great in dry matter yield and shoot/root ratio (van Keulen, 1984). The relative dry weights were $25,63,99$ and 100 , respectively, and the shoot/root ratios $1.03,1.41$, 1.80 and 1.76, respectively. These results are confirmed by the findings of Barta (1978) that during vegetative growth dry matter yield and shoot/root ratio were higher for lucerne grown at a root temperature of $30^{\circ} \mathrm{C}$ compared with $16^{\circ} \mathrm{C}$.

The characteristics of a lucerne crop canopy compared with those of a grass crop canopy can be summarized as follows:

- a lower leaf/stem ratio of lucerne than that of grass,

- a higher specific leaf area (SLA) of lucerne,

- a light interception of $90 \%$ when a crop biomass of about $2000 \mathrm{~kg} \mathrm{DM}$ per ha is attained,

- a regrowth interval, from cutting to $90-100 \%$ light interception, corresponding to that of grass.

The data found for the duration of regrowth fit well to the data of Alberda (1971) and Leafe et al. (1974) for grass.

Yield potential of lucerne can be compared with photosynthesis measurements. Sheehy et al. (1979) found that gross photosynthesis of lucerne was much higher than that of a well-fertilized grass crop during the first growth cycle. It was calculated that more than $50 \%$ of the assimilates were translocated to the roots (Wood- 
ward \& Sheehy, 1979). They assumed that the difference between gross photosynthesis and the traced amounts of dry matter was translocated to the roots. Because of this calculation procedure this figure is too high, but still relocation of assimilates to the roots of lucerne is considerable.

In comparison to the results of Woodward \& Sheehy (1979) our data for the increase of root weight, ranging from $2400 \mathrm{~kg} \mathrm{ha}^{-1}$ year $^{-1}$ in a first-year crop to zero in a third-year crop, are relatively low. More detailed studies are needed for assessing assimilate use by roots for growth, maintenance and exudation. Part of the dry matter losses are caused by senescence of roots and shoots. Assuming a loss of about 125 roots $\mathrm{m}^{-2}$ with an average dry weight of $1.5 \mathrm{~g}$, dry matter loss of roots is $1870 \mathrm{~kg}$ $\mathrm{ha}^{-1}$ in a first-year crop. In the same way the senescence of shoots causes losses in dry weight. For example, a loss of 400 shoots $\mathrm{m}^{-2}$ with an average dry weight of $0.23 \mathrm{~g}$ results in a yield loss of DM of about $1000 \mathrm{~kg} \mathrm{ha}^{-1}$ for the first cut. These estimates dot not fit to the subsequent cuts, because thinning is less and the amount of biomass of the stand is lower.

It may be hypothesized that dry matter yields of lucerne may be improved by breeding for varieties with earlier canopy development and crop growth and with a longer persistence of roots and shoots.

Dry matter yields of a first-year crop of grass, lucerne and maize ranged during the three successive growing seasons from 15.8 to 19.8 , from 13.4 to 18.1 and from 13.7 to 17.1 tonnes ha $^{-1}$, respectively. The highest yields of lucerne and maize were achieved in the growing season of 1982 with a warm and dry summer period, with grass the highest yield was found in 1980. In all comparisons first-year grass outyielded older grass crops, so it may be concluded that the potential yields of firstyear grass, lucerne and maize are around 18 tonnes ha ${ }^{-1}$ under average favourable growing conditions; however, the climatic requirements of these crops are quite different.

Although lucerne can compete with grass and maize regarding dry matter yields, this does not hold or to a less extent for the net yield of digestible organic matter, because of the lower digestibility coefficient. A limitation in the determination of digestibility in vitro is that the daily feed intake by the animal is not considered. There is evidence in the literature that the daily intake of roughage by high productive dairy cows is higher of lucerne than that of grass.

For assessing the value of lucerne as a forage crop besides yield potential also other aspects have to be considered such as problems with weeds and diseases, feed values, the availability of well-drained soils with a high $\mathrm{pH}$ and, last but not least, a good conservation of the produce. So, more research is needed on these aspects before this crop can be recommended to the farmers.

\section{References}

Alberda, Th., 1971. Potential production of grassland. In: P. F. J. Wareing \& J. P. Cooper (Eds), Potential crop production. A case study. London, Heineman, p. 159-171.

Barta, A. L., 1978. Effect of root temperature on dry matter distribution, carbohydrate accumulation and acetylene reduction activity in alfalfa and birdsfoot trefoil. Crop Science 18; 637-640. 
Heichel, G. H., D. K. Barnes \& C. P. Vance, 1981. Nitrogen fixation by forage legumes and benefits to the cropping system. Proceedings 6th Annual Symposium, Minnesota Forage and Grassland Council: 330-335.

Keulen, N. C. van, 1984. Het effect van de worteltemperatuur op de groei en de stikstofbinding by luzerne. CABO-verslag No 55 (in Dutch). CABO, Wageningen.

Leafe, E. L., W. Stiles \& Sara E. Dickinson, 1974. Physiological processes influencing the pattern of productivity of the intensively managed grass sward. Proceedings 12th International Grassland Congres, Moscow 1974.

Sheehy, J. E., F. I. Woodward, M. B. Jones \& A. Windram, 1979. Microclimate photosynthesis and growth of lucerne (Medicago sativa L.). 1. Microclimate and photosynthesis. Annals of Botany 44: 693-707.

Spiertz, J. H. J. \& L. Sibma, 1986. Dry matter production and nitrogen utilization in cropping systems with grass, lucerne and maize. 2. Nitrogen yield and utilization with various cropping systems and their after-effects. Netherlands Journal of Agricultural Science 34:37-47.

Struik, P. C., 1982. Production pattern, chemical composition and digestibility of forage maize (Zea mays L.). Vakgroep Landbouwplantenteelt en Graslandkunde, Landbouwhogeschool, Wageningen, Mededeling 64: 1-28.

Tilley, J. M. A. \& R. A. Terry, 1963. A two stage technique for the in vitro digestion of forage crops. Journal of the British Grassland Society 18: 104-111.

Woodward, F. I. \& J. E. Sheehy, 1979. Microclimate, photosynthesis and growth of lucerne (Medicago sativa L.). II. Canopy structure and growth. Annals of Botany 44: 709-719. 